\title{
The mechanism of drug interactions of a selected antiarrhythmic drug with metformin, in different animal models
}

\author{
Kayamkani Abedulla Khan ${ }^{1 *}$, Sreemantula Satyanarayana², Kilari Eswar Kumar ${ }^{3}$ \\ ${ }^{I}$ Department of Clinical Pharmacy \& Pharmacology, Ibn Sina National College for medical studies, Jeddah, Saudi Arabia, \\ ${ }^{2}$ Avanti Institute of Pharmaceutical Sciences, Cherukapally (V), Vizianagaram (Dt), India, ${ }^{3}$ A.U. College of Pharmaceutical \\ Sciences, Andhra University, Visakhapatnam, India
}

\begin{abstract}
This study was carried out to understand the influence of a selected antiarrhythmic drug on the pharmacodynamics and pharmacokinetics of an antidiabetic drug in animal models. Pharmacodynamic and pharmacokinetic responses were determined by measurements of blood glucose and serum insulin and serum metformin to drug interactions between disopyramide and metformin. Single dose and multi dose studies showed that the maximum blood glucose reductions in normal and diabetic rats were at the $6^{\text {th }}$ hour, and in rabbits at the $3^{\text {rd }}$ hour. Glucose-insulin homeostasis was evaluated to assess the safety and effectiveness of the combination. There was a marginal increase in the pharmacokinetic parameters of metformin with multiple dose treatments of disopyramide but no significant changes in kinetic parameters between single and multiple dose studies, compared to metformine alone. There may be a possibility of disopyramide and metformin interaction at the excretion stage, or an additive pharmacodynamic action. This study validates the drug interaction in two dissimilar species, which indicates more probability of its occurrence in humans.
\end{abstract}

Keywords: Disopyramide/pharmacokinetic interactions/pharmacodynamic. Metformin/ pharmacokinetic interactions/pharmacodynamic. Drug Interactions. Hypoglycaemia. Diabetes mellitus.

\section{INTRODUCTION}

Drug interactions are more serious with high risk disorders such as diabetes, hypertension, or cardiac abnormalities, or when using high risk drugs including antidiabetic and antihypertensive drugs, drugs used in congestive heart failure and antiasthmatic drugs. High risk disorders and the use of high risk drugs implies they should be observed closely and carefully. Diabetes mellitus is one such disorder, which requires vigilant management of its therapy with respect to blood glucose levels, since both hyperglycemia and hypoglycemia are undesirable.

At present, the number of patients suffering from diabetes and its associated comorbidities of atherosclerosis, dyslipidemia and other cardiac disorders, is increasing worldwide. Diabetes mellitus is a chronic metabolic disorder characterized by a rise in blood glucose level called hyperglycemia. It is of two types,

*Correspondence: K. A. Khan. Department of Clinical Pharmacy \& Pharmacology, Ibn Sina National College for Medical Studies, Jeddah, Saudi Arabia, Mobile Number: 00966548307808. E.mail: abidulla.k@gmail.com type 1 accounting for 5\% prevalence and type 2 for $95 \%$ prevalence among diabetics. The increasing prevalence of type 2 diabetes may confer $75-90 \%$ of the excess risk of diabetic retinopathy, neuropathy, nephropathy and macrovascular complications including coronary artery disease, diabetic dyslipidemia, hypertension, oxidative stress, cardiac myopathy, hyperinsulinemia, cerebrovascular disease and peripheral vascular disease. (Vinik, Flemmer 2002; Tenenbaum et al., 2004).

According to the World Health Organization (WHO, 2009 ,), 40-60\% of type 2 diabetics are obese, and have an increased likelihood of developing coronary artery disease (CAD) and other atherosclerotic manifestations. The prevalence of CAD was $21.4 \%$ among diabetics, compared to $9.1 \%$ in those with normal glucose tolerance (Mohan et al., 2001). In such a situation, there may be chances for interactions between antidiabetic and antiarrhythmic drugs, which may be beneficial or harmful. Consequently, there is a need to monitor drug therapy in polypharmacy in order to gain a better therapeutic effect with a lower rate of risk. Drug interactions may be of a pharmacokinetic or pharmacodynamic nature. 
It is now known that millions of patients take conventional medicines concomitantly, often without the knowledge of their physicians. Considering our present lack of understanding of drug interactions, proper reporting of such cases, careful vigilance, evidence based appraisals and constantly updated reviews of such information are very important to promote understanding of this area.

Biguanides are the drugs of choice for the treatment of type 2 diabetes. Metformin is a widely used biguanide. Antiarrhythmic drugs, such as sodium channel blockers, are widely used for the treatment of arrhythmias; among the sodium channel blockers, disopyramide is widely used. Disopyramide is metabolized by P450 CYP 3A4 isoenzyme in the liver (Norpace(R), 1995).

Metformin is not metabolised (Pentikainen, Koivula, Hiltunen, 1982; Glumetza(TM), 2006). It is excreted unchanged in the urine and does not undergo hepatic metabolism (no metabolites have been identified in humans) or biliary excretion (Glucophage(R), 2001). Tubular secretion is the major mechanism responsible for the elimination of metformin (Glumetza(TM), 2006). Since disopyramide, a sodium channel blocker used as an antiarrhythmic drug, is known to produce hypoglycemia due to insulin release, it may augment metformin activity by a combined pharmacodynamic mechanism. Whether it also interferes with the pharmacokinetics of metformin is not known, so it is necessary to establish the safety of this combination.

The present study was undertaken to understand the influence of a selected antiarrhythmic drug (disopyramide) on the pharmacodynamics of an antidiabetic drug (metformin) in normal and diabetic rats, and the pharmacodynamics and pharmacokinetics in normal rabbits. This study is planned to establish the safety of the drug combination in two dissimilar species of animal models, namely rats and rabbits, with respect to blood glucose level and serum insulin, and to establish the mechanisms responsible for the interactions, if any. The outcome of the work provides information which has clinical utility.

\section{MATERIAL AND METHODS}

A sample of metformin (100g) was obtained from Dr. Reddys Laboratories, Hyderabad, India; and a sample of disopyramide $(10 \mathrm{~g})$ was obtained from RPG Life Sciences Ltd., Mumbai. Also obtained were acetonitrile (HPLC grade) manufactured by Qualigens Chemicals, Mumbai, India, potassium dihydrogen phosphate (AR Grade), and orthophosphoric acid, both manufactured by Fine Chemicals, Mumbai, India. Triple distilled water was prepared in the laboratory. Blood glucose kits (Auto span) manufactured by Span Diagnostics Ltd, Surat, India, were purchased from a local community pharmacy. A standard animal pellet diet was used, manufactured by Rayan Biotechnologies Pvt. Ltd, Hyderabad, India.

Inbred adult albino rabbits and albino rats (Wistar strain) of both genders were purchased from Sainath Agencies, Hyderabad, India. They were maintained under standard laboratory conditions at an ambient temperature of $25 \pm 2{ }^{\circ} \mathrm{C}$ and $50 \pm 15 \%$ relative humidity with a $12 \mathrm{~h} \mathrm{light}$ and $12 \mathrm{~h}$ dark cycle. They were fed with the commercial pellet diet and water ad libitum. The experimental protocol was approved by the Institutional Animal Ethics Committee (IAEC/SUCP/05/2010]. Rats were fasted for $18 \mathrm{~h}$ prior to the experiment, allowing access to water. During the experiment, food and water were withdrawn.

Pharmacokinetic and pharmacodynamic responses were determined related to the selected drug disopyramide given alone, and in combination with the antidiabetic drug, metformin. The results were compared using the unpaired Student's t-test to determine statistical significance.

\section{Estimation of metformin from rabbit serum by HPLC}

An isocratic high performance liquid chromatography (HPLC) was used, equipped with automated waters, 2695 pump model, variable wavelength programmable DAD or UV detector no: 2487, Symmetry C18 (4.6 x 150mm, 5 $\mu \mathrm{m}$, Make: XTerra) or equivalent, particle size $5 \mu \mathrm{m}$. The HPLC system was equipped with the software Empower 2 (Waters).

The mobile phase consisted of a phosphate buffer and acetonitrile (HPLC grade; Qualigens, Mumbai, India). The mobile phase components were filtered before use through a $0.45 \mathrm{~m}$ membrane filter and pumped in the ratio of 35:65 pH3, adjusted with orthophosphoric acid (phosphate buffer: acetonitrile from the respective solvent reservoirs). The flow rate of the mobile phase was maintained at $0.8 \mathrm{~mL} / \mathrm{min}$ and the column temperature was maintained at $40{ }^{\circ} \mathrm{C}$. The eluent was monitored at $240 \mathrm{~nm}$ wavelength with the DAD or UV detector on the C-18 column.

\section{Plasma sample treatment}

To $0.5 \mathrm{~mL}$ of serum in a $1.5 \mathrm{~mL}$ Eppendrof tube, $0.5 \mathrm{~mL}$ acetonitrile was added to precipitate proteins and extract metformin. The Eppendrof tubes were vortexmixed for 5 min to bring about the complete extraction of metformin from the proteins and, after standing for 10 
min, the tubes were centrifuged at $5000 \mathrm{rpm}$ for $10 \mathrm{~min}$. The upper layer (about $100 \mu \mathrm{L}$ ) was separated with the help of a syringe and filtered through $0.45 \mu \mathrm{m}, 13 \mathrm{~mm}$ nylon membrane filters (Pall Life Sciences, Mumbai, India). About $20 \mu \mathrm{L}$ of filtrate was injected in the HPLC system. The eluent was detected by UV detector at $240 \mathrm{~nm}$, and the data were acquired, stored and analyzed with the software Empower 2 (Waters). Calibration samples were prepared by spiking $200 \mu \mathrm{L}$ of the individual blank serum with the appropriate amount of drug on the day of analysis. Samples for the determination of recovery, precision and accuracy were prepared by spiking the control rabbit serum in bulk of appropriate concentrations $(50,100,200$, 500 and $1000 \mathrm{ng} / \mathrm{mL}$ ) and stored at $-4{ }^{\circ} \mathrm{C}$.

\section{Normal rats}

The normal albino rats of either sex were divided into four groups of six each. All the rats weighing between 165 to $250 \mathrm{~g}$ were given different drugs orally, as follows: Group I: disopyramide $3.6 \mathrm{mg} / 200 \mathrm{~g}$ body weight.

Group II: metformin (2TD) 2 X Therapeutic Dose 18 $\mathrm{mg} / 200 \mathrm{~g}$ body weight.

Group III: disopyramide $3.6 \mathrm{mg} / 200 \mathrm{~g}$ body weight and then after $30 \mathrm{~min}$ metformin $18 \mathrm{mg} / 200 \mathrm{~g}$ body weight.

Group IV: disopyramide for 7 days with regular feeding, later after $18 \mathrm{~h}$ of fast they were again given the combined dose (disopyramide + metformin) on the $8^{\text {th }}$ day.

\section{Diabetic rats}

\section{Induction of diabetes}

Albino rats of either sex were used for the induction of diabetes. These animals were injected with a freshly prepared aqueous solution of alloxan monohydrate in two doses of $100 \mathrm{mg} / \mathrm{kg}$ and $50 \mathrm{mg} / \mathrm{kg}$ body weight intraperitoneally for two consecutive days. Then $10 \%$ dextrose was administered to combat the immediate hypoglycemia. Blood sugar was measured and rats showing fasting blood sugar levels above $250 \mathrm{mg} / \mathrm{dL}$ were selected for the study.

The diabetic rats were divided into four groups of six each. All the rats, weighing between 165 to $250 \mathrm{~g}$, were given different drugs orally, as follows:

Group I: disopyramide $3.6 \mathrm{mg} / 200 \mathrm{~g}$ body weight.

Group II: metformin 2TD $18 \mathrm{mg} / 200 \mathrm{~g}$ body weight.

Group III: disopyramide $3.6 \mathrm{mg} / 200 \mathrm{~g}$ body weight and then after $30 \mathrm{~min}$, metformin $18 \mathrm{mg} / 200 \mathrm{~g}$ body weight.

Group IV: disopyramide for the 7 days with regular feeding; later, after $18 \mathrm{~h}$ of fast, they were given the combined dose (disopyramide + metformin) on the 8 th day.
Blood samples, drawn from a retro orbital puncture, were estimated for blood glucose from all the above groups of normal and diabetic rats. The blood samples were collected at $0,1,2,3,4,6,8,10$ and $12 \mathrm{~h}$ intervals from all the groups of rats after drug administration and were subjected to estimation of blood glucose by the GOD/POD method; serum insulin was estimated by radioimmunoassay; and the insulin resistance index and $\beta$-cell function were determined by homeostasis model assessment. All the drugs were administered orally.

\section{Rabbits}

A group of six rabbits was given metformin 2TD $70 \mathrm{mg} / 1.5 \mathrm{~kg}$ body weight, followed by a one week period of washout, then the same group of rabbits was given disopyramide $14 \mathrm{mg} / 1.5 \mathrm{~kg}$ body weight. Later on washout period for one week, then same group was given disopyramide $14 \mathrm{mg} / 1.5 \mathrm{~kg}$, orally $30 \mathrm{mins}$ prior to the administration of metformin (2TD) $70 \mathrm{mg} / 1.5 \mathrm{~kg}$ body weight.

Then, after the one week washout period, a similar group of rabbits were given disopyramide $14 \mathrm{mg} / 1.5 \mathrm{~kg}$ body weight for 7 days continuously; on the $8^{\text {th }}$ day, disopyramide $14 \mathrm{mg} / 1.5 \mathrm{~kg}$ body weight was given orally $30 \mathrm{mins}$ prior to the administration of metformin (2TD) $70 \mathrm{mg} / 1.5 \mathrm{~kg}$. Blood samples were withdrawn at $0,1,2,3,4,6,8,12,16,20$ and $24 \mathrm{~h}$ intervals from a marginal ear vein puncture and were analyzed for blood glucose by the GOD/POD method; serum insulin was estimated by radioimmunoassay in a fully automated 12 well multi gamma counter radioimmunoassay system using ${ }^{125}$ I (PC RIA MAS, Stratee, Germany); and the insulin resistance index and $\beta$-cell function were determined by homeostasis model assessment.

HOMA-2: the updated HOMA computer model, that estimates the insulin resistance index, $\beta$-cell function and insulin sensitivity, was obtained from the program HOMA calculator v 2.2.3 (Oxford Centre for Diabetes Endocrinology and Metabolism, 2009).

The results were expressed as micro international units $/ \mathrm{mL}(\mu \mathrm{IU} / \mathrm{mL})$ for serum insulin and serum metformin, estimated by the HPLC method. The pharmacokinetic parameters were calculated from the blood metformin data using the kinetic software RAMKIN.

\section{RESULTS AND DISCUSSION}

\section{Chromatography}

The calibration curve was linear over the concentration range of $300 \mathrm{ng} / \mathrm{mL}$ to $2000 \mathrm{ng} / \mathrm{mL}$. The 
limit of quantification (LOQ) was estimated to be 300ng/ $\mathrm{mL}$ by analyzing the drug at low concentrations of the calibration curves. To establish the limit of determination (LOD), lesser plasma concentrations than the LOQ were used; the LOD was found to be about $15 \mathrm{ng} / \mathrm{mL}$ (signalto-noise ratio of 3) shown in Figures 1 and 2.

\section{Accuracy and precision}

For the purpose of determining the intraday and interday accuracy and precision, the concentration of metformin used in five replicates of plasma spiked with $300,600,900,1200$ and $1500 \mathrm{ng} / \mathrm{mL}$ metformin was estimated by HPLC within a day, or on different days. The values were found within the limits $(<15 \%)$ specified for inter and intraday precision.

\section{Recovery}

The recovery of metformin from plasma was estimated at 300,600,900, 1200 and $1500 \mathrm{ng} / \mathrm{mL}$ concentrations by comparing the peak areas of the spiked plasma standards with those of the corresponding plain standards containing the corresponding concentration in the mobile phase that represented recovery was $99.32 \%$, $100.81 \%, 98.77 \%, 98.99 \%$ and $100.67 \%$.

\section{Normal rats}

Disopyramide induced hypoglycemia was studied by administering doses TD $3.6 \mathrm{mg} / 200 \mathrm{~g}$ bodyweight. Disopyramide produced a peak blood glucose reduction of $35.94 \pm 06.70 \%$ at $6 \mathrm{~h}$, and serum insulin levels were $10.55 \pm 3.78 \mu \mathrm{U} / \mathrm{mL}$ at $6 \mathrm{~h}$.

Metformin 2TD (18mg/200g body weight) produced $31.30 \pm 03.50 \%$ peak reduction at $6 \mathrm{~h}$ and the serum insulin level was $11.82 \pm 1.56 \mu \mathrm{U} / \mathrm{mL}$ at $6 \mathrm{~h}$. In the disopyramide combination, metformin produced a peak reduction of $43.09 \pm 02.40 \%$ at $6 \mathrm{~h}$ and the serum insulin level was $12.84 \pm 3.67 \mu \mathrm{U} / \mathrm{mL}$ at $6 \mathrm{~h}$. Compared to the metformin control, the combination with metformin enhanced the percentage of blood glucose reduction and insulin level.

The multiple dose of disopyramide and metformin produced a peak blood glucose reduction of $45.93 \pm$ $03.56 \%$ at $6 \mathrm{~h}$ and the serum insulin level was $15.20 \pm$ $6.98 \mu \mathrm{U} / \mathrm{mL}$. Compared to the individual drug and single dose drug combination, the multiple dose combination with metformin enhanced glucose reduction, as shown in Tables I and II, and Figure 3.

\section{Diabetic rats}

Metformin, 2TD (18 mg/200 g body weight) produced a reduction in blood glucose with a peak activity of $40.22 \pm 01.58 \%$ at $6 \mathrm{~h}$ and a serum insulin level of 10.84 $\pm 6.7 \mu \mathrm{U} / \mathrm{mL}$ at $6 \mathrm{~h}$. Disopyramide induced hypoglycemia was studied by administering doses TD $3.6 \mathrm{mg} / 200 \mathrm{~g}$ bodyweight. It reduced blood glucose with $39.20 \pm 01.90 \%$ as peak activity at $6 \mathrm{~h}$ and the serum insulin level was $10.56 \pm 2.1 \mu \mathrm{U} / \mathrm{mL}$ at $6 \mathrm{~h}$.

The disopyramide single dose with metformin combination produced a peak reduction of blood glucose $47.23 \pm 01.99 \%$ at $6 \mathrm{~h}$ and the serum insulin level was $11.89 \pm 9.2 \mu \mathrm{U} / \mathrm{mL}$ at $6 \mathrm{~h}$. Compared to the metformin matched control, the combination with metformin enhanced the glucose reduction.

The multiple dose combination of disopyramide with metformin produced a peak blood glucose reduction of $49.04 \pm 02.81 \%$ at $6 \mathrm{~h}$ and the serum insulin level was $12.13 \pm 9.3 \mu \mathrm{U} / \mathrm{mL}$ at $6 \mathrm{~h}$. Compared to the individual drug and single dose combination, multiple dose combination

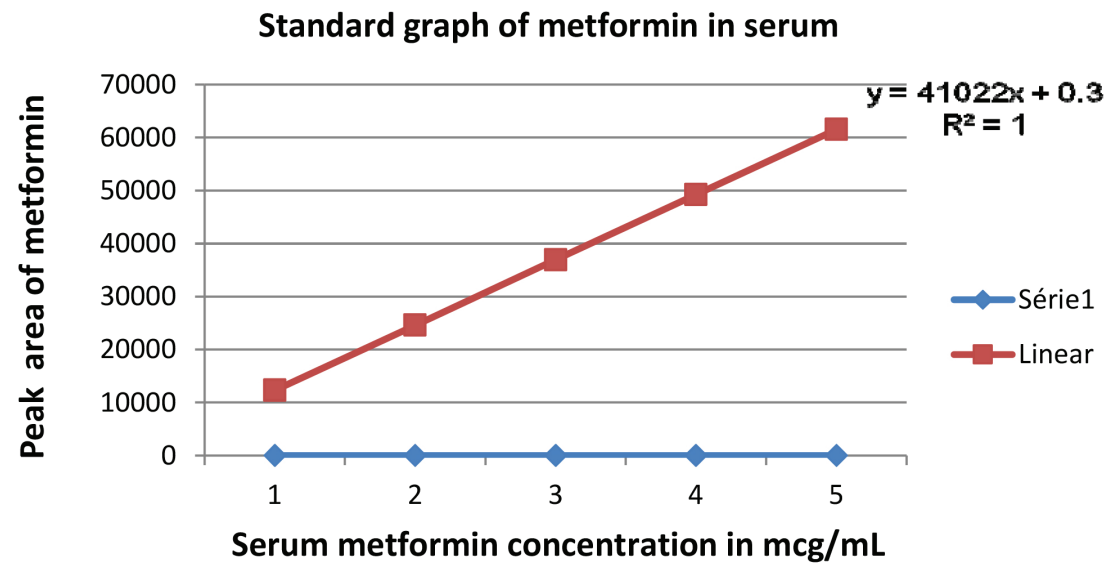

FIGURE 1 - Standard graph of metformin in serum. 


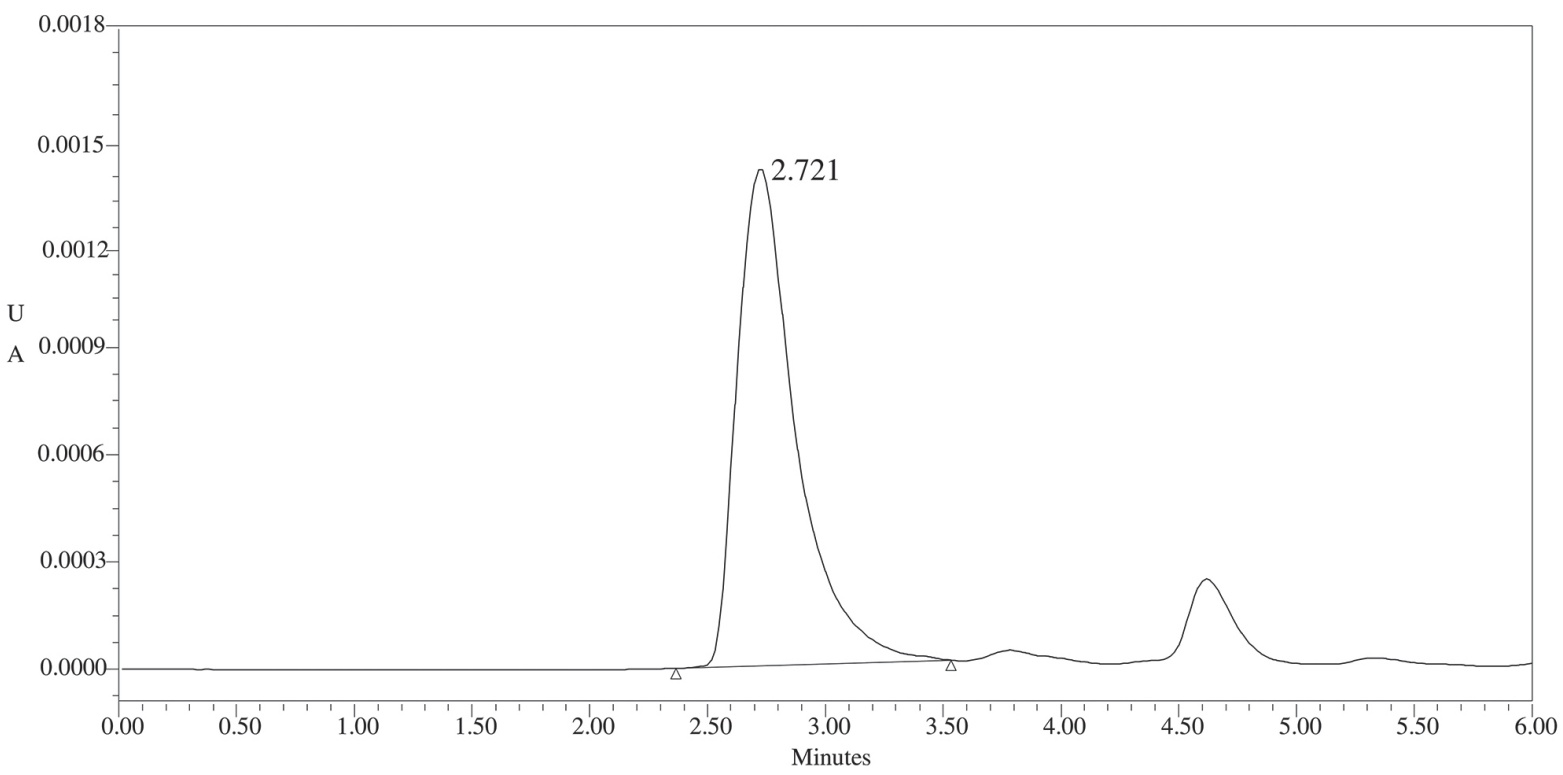

\begin{tabular}{|c|c|r|c|c|}
\hline & Name & $\begin{array}{c}\text { Retention Time } \\
(\mathrm{min})\end{array}$ & $\begin{array}{c}\text { Area } \\
\left(\mu \mathrm{V}^{*} \mathrm{sec}\right)\end{array}$ & $\begin{array}{c}\text { Height } \\
(\mu \mathrm{V})\end{array}$ \\
\hline 1 & Metformin & 2.721 & 16409 & 1517 \\
\hline
\end{tabular}

FIGURE 2 - Typical chromatogram of metformin.

with metformin enhanced the glucose reduction and serum insulin levels, as shown in Tables II and III.

\section{Normal rabbits}

Metformin 2TD $(70 \mathrm{mg} / 1.5 \mathrm{~kg}$ body weight $)$ produced a reduction in blood glucose level with a peak activity of $31.09 \pm 01.54 \%$ at the $3 \mathrm{rd} h$, and a maximum serum metformin concentration was found of $1184 \pm 35.70$ $\mathrm{ng} / \mathrm{mL}$ at the $3 \mathrm{rd} \mathrm{h}$. The serum insulin was found to be
$10.84 \pm 3.45 \mu \mathrm{U} / \mathrm{mL}$ at the $3 \mathrm{rd} \mathrm{h}$ with metformin treatment in normal rabbits.

In the single dose study of disopyramide with metformin, the maximum reduction in blood glucose, that is, $41.14 \pm 03.18 \%$ at the $3 \mathrm{rd} h$ was observed, and an increase in serum insulin level of $15.87 \pm 1.51 \mu \mathrm{U} / \mathrm{mL}$ at the $3 \mathrm{rd} \mathrm{h}$ with disopyramide and also a slight increase in peak serum metformin concentration of $1209 \pm 17.62 \mathrm{ng} /$ $\mathrm{mL}$ at the $3 \mathrm{rd} \mathrm{h}$ in normal rabbits.

In the multiple dose study of disopyramide with

TABLE I - Percentage blood glucose reduction after oral administration of metformin $18 \mathrm{mg} / 200 \mathrm{~g}$ body weight, disopyramide $3.6 \mathrm{mg} / 200 \mathrm{~g}$ body weight, disopyramide single dose study and multiple dose study in normal rats $(\mathrm{n}=6)$

\begin{tabular}{lcccc}
\hline \multirow{2}{*}{ Time (h) } & \multicolumn{4}{c}{ Mean percentage blood glucose reduction \pm SD } \\
\cline { 2 - 5 } & Metformin & Disopyramide & Single dose combination & Multiple dose combination \\
\hline 1 & $11.35 \pm 00.97$ & $22.98 \pm 05.38$ & $14.51 \pm 01.48$ & $14.86 \pm 01.94$ \\
2 & $19.11 \pm 04.08$ & $32.30 \pm 06.12$ & $23.08 \pm 01.81$ & $25.76 \pm 01.67$ \\
3 & $23.42 \pm 03.49$ & $32.14 \pm 07.10$ & $33.46 \pm 01.19^{* *}$ & $34.92 \pm 02.13^{* *}$ \\
4 & $28.26 \pm 04.60$ & $28.75 \pm 05.87$ & $41.24 \pm 01.90^{* * *}$ & $44.78 \pm 03.45^{* * *}$ \\
$\mathbf{6}$ & $\mathbf{3 1 . 3 0} \pm \mathbf{0 3 . 5 0}$ & $\mathbf{3 5 . 9 4} \pm \mathbf{0 6 . 7 0}$ & $\mathbf{4 3 . 0 9} \pm \mathbf{0 2 . 4 0 * * *}$ & $\mathbf{4 5 . 9 3} \pm \mathbf{0 3 . 5 6 * * *}$ \\
8 & $24.37 \pm 02.60$ & $18.70 \pm 01.46$ & $35.19 \pm 02.07$ & $38.51 \pm 03.49$ \\
10 & $18.24 \pm 04.57$ & $10.60 \pm 02.42$ & $25.14 \pm 02.99$ & $29.22 \pm 03.91$ \\
12 & $11.94 \pm 04.26$ & $05.41 \pm 00.82$ & $15.28 \pm 01.45$ & $16.46 \pm 02.95^{*}$ \\
\hline
\end{tabular}

*** Significant at $\mathrm{P}<0.001$; ** Significant at $\mathrm{P}<0.01$; *Significant at $\mathrm{P}<0.05$ compared to control metformin $2 \mathrm{TD}$. 
TABLE II - Percentage blood glucose reduction after oral administration of metformin $18 \mathrm{mg} / 200 \mathrm{~g}$ body weight, disopyramide $3.6 \mathrm{mg} / 200 \mathrm{~g}$ body weight, disopyramide single dose study and multiple dose study in diabetic rats $(\mathrm{n}=6)$

\begin{tabular}{lcccc}
\hline \multirow{2}{*}{ Time (h) } & \multicolumn{4}{c}{ Mean percentage blood glucose reduction \pm SD } \\
\cline { 2 - 5 } & Metformin & Disopyramide & Single dose combination & Multiple dose combination \\
\hline 1 & $12.83 \pm 01.19$ & $22.90 \pm 01.13$ & $14.81 \pm 01.30$ & $14.37 \pm 01.30$ \\
2 & $24.72 \pm 03.52$ & $30.30 \pm 03.15$ & $24.75 \pm 02.05$ & $27.14 \pm 01.30$ \\
3 & $31.98 \pm 03.53$ & $30.90 \pm 02.70$ & $35.40 \pm 02.33$ & $35.77 \pm 01.16$ \\
4 & $37.16 \pm 02.11$ & $31.50 \pm 04.90$ & $44.74 \pm 02.02$ & $47.42 \pm 03.11$ \\
$\mathbf{6}$ & $\mathbf{4 0 . 2 2} \pm \mathbf{0 1 . 5 8}$ & $\mathbf{3 9 . 2 0} \pm \mathbf{0 1 . 9 0}$ & $\mathbf{4 7 . 2 3} \pm \mathbf{0 1 . 9 9 * * *}$ & $\mathbf{4 9 . 0 4} \pm \mathbf{0 2 . 8 1 ^ { * * * }}$ \\
8 & $29.81 \pm 01.66$ & $18.41 \pm 00.70$ & $42.44 \pm 01.50^{* *}$ & $43.76 \pm 02.66^{* *}$ \\
10 & $21.72 \pm 05.03$ & $13.10 \pm 01.60$ & $28.39 \pm 03.27^{*}$ & $29.12 \pm 01.63^{* *}$ \\
12 & $14.33 \pm 02.48$ & $06.27 \pm 01.00$ & $15.47 \pm 02.52$ & $15.85 \pm 01.05$ \\
\hline
\end{tabular}

*** Significant at $\mathrm{P}<0.001$; ** Significant at $\mathrm{P}<0.01$; *Significant at $\mathrm{P}<0.05$ compared to control metformin $2 \mathrm{TD}$.

TABLE III - Effect of disopyramide on the activity of metformin in normal rats and diabetic rats $(\mathrm{N}=6)$

\begin{tabular}{|c|c|c|c|c|c|c|c|c|c|c|c|c|}
\hline \multirow[t]{2}{*}{ Parameter } & \multicolumn{3}{|c|}{ Metformin } & \multicolumn{3}{|c|}{ Disopyramide } & \multicolumn{3}{|c|}{$\begin{array}{c}\text { Disopyramide }+ \text { metformin } \\
\text { (SDA) }\end{array}$} & \multicolumn{3}{|c|}{$\begin{array}{c}\text { Disopyramide + metformin } \\
\text { (MDA) }\end{array}$} \\
\hline & $3^{\text {rd } h}$ & $6^{\text {th }} \mathbf{h}$ & $12^{\text {th }} \mathrm{h}$ & $3^{\text {rd } h}$ & $6^{\text {th }} \mathbf{h}$ & $12^{\text {th }} h$ & $3^{\text {rd } h}$ & $6^{\text {th }} \mathbf{h}$ & $12^{\text {th }} h$ & $3^{\text {rd } h}$ & $6^{\text {th }} h$ & $12^{\text {th }} h$ \\
\hline Glucose (m g/dL) & $\begin{array}{c}62.83 \pm \\
04.50\end{array}$ & $\begin{array}{c}56.33 \pm \\
02.10\end{array}$ & $\begin{array}{l}72.16 \pm \\
02.13\end{array}$ & $\begin{array}{c}64.50 \pm \\
06.60\end{array}$ & $\begin{array}{c}60.83 \pm \\
05.30\end{array}$ & $\begin{array}{c}90.00 \pm \\
04.33\end{array}$ & $\begin{array}{l}60.16 \pm \\
02.63\end{array}$ & $\begin{array}{c}51.50 \pm \\
03.70\end{array}$ & $\begin{array}{c}76.66 \pm \\
04.45\end{array}$ & $\begin{array}{c}57.16 \pm \\
05.11\end{array}$ & $\begin{array}{c}47.66 \pm \\
06.80\end{array}$ & $\begin{array}{c}73.50 \pm \\
07.91\end{array}$ \\
\hline Insulin resistance & $\begin{array}{c}1.19 \pm \\
0.12\end{array}$ & $\begin{array}{c}1.32 \pm \\
0.34\end{array}$ & $\begin{array}{c}1.14 \pm \\
0.43\end{array}$ & $\begin{array}{c}1.16 \pm \\
0.97\end{array}$ & $\begin{array}{c}1.22 \pm \\
0.25\end{array}$ & $\begin{array}{c}0.93 \pm \\
0.56\end{array}$ & $\begin{array}{c}1.25 \pm \\
0.74\end{array}$ & $\begin{array}{c}1.63 \pm \\
0.96\end{array}$ & $\begin{array}{c}1.08 \pm \\
0.39\end{array}$ & $\begin{array}{c}1.30 \pm \\
0.84\end{array}$ & $\begin{array}{c}1.78 \pm \\
0.76\end{array}$ & $\begin{array}{c}1.07 \pm \\
0.57\end{array}$ \\
\hline$\beta$-cell function & $\begin{array}{l}236.9 \pm \\
20.12\end{array}$ & $\begin{array}{l}325 \pm \\
13.45\end{array}$ & $\begin{array}{c}169.3 \pm \\
17.89\end{array}$ & $\begin{array}{c}219.3 \pm \\
34.2\end{array}$ & $\begin{array}{c}258.6 \pm \\
25.76\end{array}$ & $\begin{array}{c}90.40 \pm \\
27.82\end{array}$ & $\begin{array}{c}270.4 \pm \\
16.23\end{array}$ & $\begin{array}{c}402.50 \pm \\
19.12 *\end{array}$ & $\begin{array}{c}143.5 \pm \\
26.12\end{array}$ & $\begin{array}{c}311.3 \pm \\
35.12\end{array}$ & $\begin{array}{l}607.5 \pm \\
45.12^{*}\end{array}$ & $\begin{array}{c}155.50 \pm \\
10.23\end{array}$ \\
\hline $\begin{array}{l}\text { Insulin action or } \\
\text { sensitivity }(\% \mathrm{~S})\end{array}$ & $\begin{array}{c}84.2 \pm \\
5.61 \\
\end{array}$ & $\begin{array}{c}75.7 \pm \\
7.43\end{array}$ & $\begin{array}{c}87.9 \pm \\
6.78 \\
\end{array}$ & $\begin{array}{c}86.4 \pm \\
8.92 \\
\end{array}$ & $\begin{array}{c}82.30 \pm \\
9.23\end{array}$ & $\begin{array}{c}108.0 \pm \\
21.78\end{array}$ & $\begin{array}{l}80.0 \pm \\
20.11\end{array}$ & $\begin{array}{c}61.35 \pm \\
10.94\end{array}$ & $\begin{array}{c}92.20 \pm \\
11.45\end{array}$ & $\begin{array}{l}77.0 \pm \\
12.56\end{array}$ & $\begin{array}{c}56.17 \pm \\
17.34\end{array}$ & $\begin{array}{c}93.60 \pm \\
08.12\end{array}$ \\
\hline Insulin $(\mu \mathrm{U} / \mathrm{mL})$ & $\begin{array}{l}8.8 \pm \\
4.76\end{array}$ & $\begin{array}{c}10.84 \pm \\
6.7\end{array}$ & $\begin{array}{c}6.8 \pm \\
3.2\end{array}$ & $\begin{array}{c}8.6 \pm \\
6.2\end{array}$ & $\begin{array}{c}10.56 \pm \\
2.1\end{array}$ & $\begin{array}{c}6.2 \pm \\
1.8\end{array}$ & $\begin{array}{c}7.5 \pm \\
4.7\end{array}$ & $\begin{array}{c}11.89 \pm \\
9.2\end{array}$ & $\begin{array}{c}6.43 \pm \\
8.2\end{array}$ & $\begin{array}{c}8.12 \pm \\
7.4\end{array}$ & $\begin{array}{c}12.13 \pm \\
9.3\end{array}$ & $\begin{array}{c}6.4 \pm \\
9.2\end{array}$ \\
\hline Insulin resistance & $\begin{array}{c}1.35 \pm \\
0.54\end{array}$ & $\begin{array}{c}1.61 \pm \\
0.43\end{array}$ & $\begin{array}{c}1.14 \pm \\
0.67\end{array}$ & $\begin{array}{c}1.32 \pm \\
0.58\end{array}$ & $\begin{array}{c}1.56 \pm \\
0.83\end{array}$ & $\begin{array}{c}1.11 \pm \\
0.74\end{array}$ & $\begin{array}{c}1.19 \pm \\
0.24\end{array}$ & $\begin{array}{c}1.72 \pm \\
0.62\end{array}$ & $\begin{array}{c}1.08 \pm \\
0.81\end{array}$ & $\begin{array}{c}1.28 \pm \\
0.92\end{array}$ & $1.75 \pm 0.36$ & $\begin{array}{c}1.08 \pm \\
0.56\end{array}$ \\
\hline$\beta$-cell function & $\begin{array}{c}24.1 \pm \\
8.65\end{array}$ & $\begin{array}{c}35.4 \pm \\
7.54\end{array}$ & $\begin{array}{c}13.0 \pm \\
4.65\end{array}$ & $\begin{array}{c}23.2 \pm \\
7.89\end{array}$ & $\begin{array}{c}34.3 \pm \\
6.89\end{array}$ & $\begin{array}{c}10.4 \pm \\
2.87\end{array}$ & $\begin{array}{c}17.0 \pm \\
3.43\end{array}$ & $\begin{array}{l}45.3 \pm \\
7.51^{*}\end{array}$ & $\begin{array}{c}12.1 \pm \\
3.15\end{array}$ & $\begin{array}{c}18.9 \pm \\
5.42\end{array}$ & $\begin{array}{l}49.1 \pm \\
9.76^{*}\end{array}$ & $\begin{array}{c}12.2 \pm \\
1.12\end{array}$ \\
\hline $\begin{array}{l}\text { Insulin action or } \\
\text { sensitivity }(\% \mathrm{~S})\end{array}$ & $\begin{array}{l}74.1 \pm \\
11.23\end{array}$ & $\begin{array}{c}62.2 \pm \\
8.45\end{array}$ & $\begin{array}{c}87.6 \pm \\
12.32\end{array}$ & $\begin{array}{c}75.6 \pm \\
9.76\end{array}$ & $\begin{array}{c}63.9 \pm 7 \\
.32\end{array}$ & $\begin{array}{c}89.9 \pm \\
13.23\end{array}$ & $\begin{array}{c}83.7 \pm \\
12.45\end{array}$ & $\begin{array}{c}58.2 \pm \\
9.74\end{array}$ & $\begin{array}{c}92.3 \pm \\
17.45\end{array}$ & $\begin{array}{c}78.1 \pm \\
18.65\end{array}$ & $\begin{array}{c}57.2 \pm \\
12.21\end{array}$ & $\begin{array}{c}92.5 \pm \\
9.84\end{array}$ \\
\hline
\end{tabular}

Notes: Data were expressed as mean $\pm \mathrm{SD}(\mathrm{N}=6)$; s significant at $\mathrm{P}<0.05$ compared to metformin control. Abbreviations: SDA - single dose administration; MDA- multi dose administration.

metformin, the maximum reduction in blood glucose of $43.11 \pm 03.52 \%$ was noted at the $3 \mathrm{rd} \mathrm{h}$, and the serum insulin of $18.76 \pm 7.58 \mu \mathrm{U} / \mathrm{mL}$ at the $3 \mathrm{rd} \mathrm{h}$. The peak serum metformin concentration was $1219 \pm 17.33 \mathrm{ng} / \mathrm{mL}$ at the $3 \mathrm{rd} \mathrm{h}$ in normal rabbits, as described in Tables IV, $\mathrm{V}$ and VI.

The etiology of diabetes involves several factors; and it is considered as an autoimmune disorder (Castano, 
The mechanism of drug interactions of a selected antiarrhythmic drug with metformin, in different animal models

TABLE IV- Percentage blood glucose reduction after oral administration of metformin $70 \mathrm{mg} / 1.5 \mathrm{~kg}$ body weight, disopyramide $14 \mathrm{mg} / 1.5 \mathrm{~kg}$ body weight, disopyramide single dose study and multiple dose study in normal rabbits $(\mathrm{n}=6)$

\begin{tabular}{|c|c|c|c|c|}
\hline \multirow{2}{*}{ Time (h) } & \multicolumn{4}{|c|}{ Mean percentage blood glucose reduction \pm SD } \\
\hline & Metformin & Disopyramide & Single dose combination & Multiple dose combination \\
\hline 1 & $10.77 \pm 01.98$ & $09.70 \pm 03.31$ & $12.34 \pm 02.31$ & $13.60 \pm 01.84 *$ \\
\hline 2 & $26.22 \pm 02.63$ & $17.63 \pm 01.90$ & $28.82 \pm 02.69$ & $31.16 \pm 03.53 *$ \\
\hline 3 & $31.09 \pm 01.54$ & $24.83 \pm 02.40$ & $41.14 \pm 03.18 * * *$ & $43.11 \pm 03.52 * *$ \\
\hline 4 & $27.74 \pm 04.22$ & $28.16 \pm 02.20$ & $38.23 \pm 03.09 * * *$ & $39.09 \pm 04.16^{* *}$ \\
\hline 6 & $25.32 \pm 02.90$ & $21.96 \pm 01.90$ & $33.25 \pm 03.85^{* *}$ & $33.04 \pm 02.90^{* *}$ \\
\hline 8 & $19.38 \pm 01.20$ & $17.20 \pm 01.40$ & $24.48 \pm 02.76^{* *}$ & $25.19 \pm 04.01 *$ \\
\hline 12 & $14.13 \pm 02.20$ & $12.53 \pm 00.80$ & $16.42 \pm 03.34$ & $18.21 \pm 03.25^{*}$ \\
\hline 16 & $8.37 \pm 01.89$ & $09.68 \pm 01.20$ & $12.36 \pm 02.37^{*}$ & $14.07 \pm 01.49$ \\
\hline 20 & $1.26 \pm 00.49$ & $07.46 \pm 01.20$ & $07.31 \pm 01.60^{* *}$ & $09.14 \pm 02.61 *$ \\
\hline 24 & $0.92 \pm 00.23$ & $01.25 \pm 00.40$ & $05.50 \pm 00.93$ & $06.17 \pm 01.22$ \\
\hline
\end{tabular}

*** Significant at $\mathrm{P}<0.001$; ** Significant at $\mathrm{P}<0.01$; *Significant at $\mathrm{P}<0.05$ compared to control metformin $2 \mathrm{TD}$.

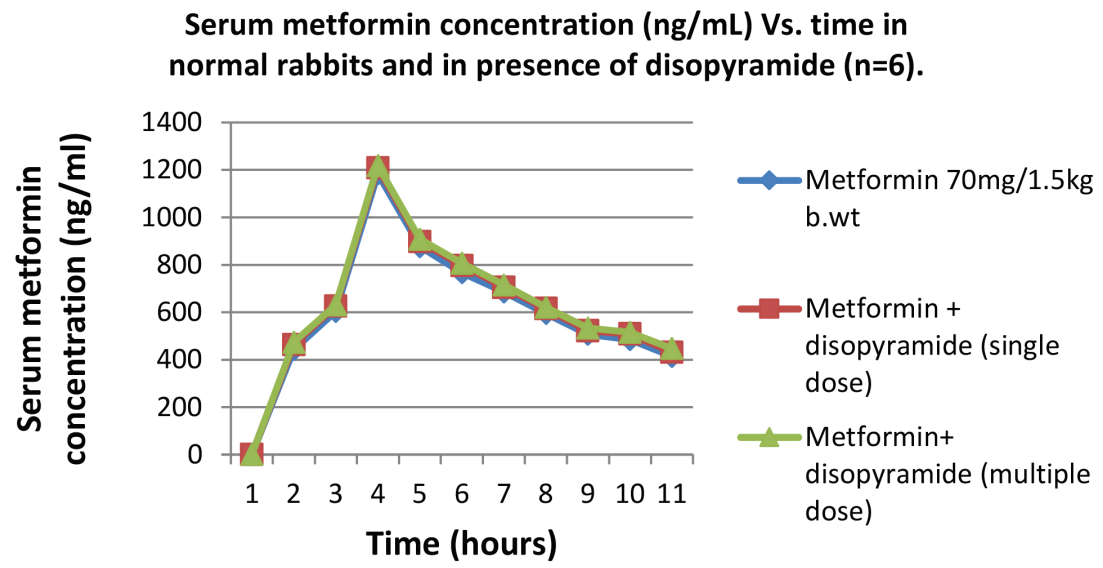

FIGURE 3 - Serum metformin concentration $(\mathrm{ng} / \mathrm{mL})$ vs. time in normal rabbits and in presence of disopyramide $(\mathrm{n}=6)$.

Eisenbarth, 1990). The major factor considered to be involved is stress, which is particularly so in the case of type-2 diabetes (Lloyd, Smith, Weinger, 2005). Moreover, whether it is type 1 or type 2 diabetes, when the disease becomes chronic it leads to a further increase in stress due to hyperglycemia and the increased oxidation of glucose, leading to several comorbid conditions including cardiac disorders, retinopathy, nephropathy and neuropathy. Hence, the treatment of diabetes should be aimed at controlling hyperglycemia along with cardiac disorders, such as arrhythmias. Antidiabetic and antiarrhythmic drug treatments are given simultaneously to control blood glucose and arrhythmias, respectively.

The doses of selected drugs administered to the rats and rabbits were calculated, based on human therapeutic dose (TD) and extrapolated to animals, based on body surface area using the formula in the rat dose $=0.018 \times$ human TD; and the rabbit dose $=0.07 \times$ human TD $($ Ghosh, 1984). Such doses were taken as the TD depending on their effect, particularly regarding the antidiabetic drugs; suitable doses that produced a $30-45 \%$ of blood glucose reduction were arrived at and these doses were employed for the interaction studies.

Disopyramide is an antiarrhythmic drug with a sodium channel blockade mechanism, and induces hypoglycemia. Hypoglycemia is thought to be due to pancreatic $\beta$ cell over production of insulin because sodium channel blockers inhibit sodium ions and increase the concentration of intracellular ATP by lowering the consumption of ATP. This action inhibits ionic $\mathrm{K}^{+} \mathrm{ATP}$ and causes depolarization of the $\beta$ cells, followed by activating calcium channels, increasing calcium concentration, which is followed by an increased release of insulin.

Metformin is a widely used drug in the treatment of 
TABLE V - Effect of disopyramide on the activity of metformin in normal rabbits $(\mathrm{N}=6)$

\begin{tabular}{|c|c|c|c|c|c|c|c|c|c|c|c|c|}
\hline \multirow[t]{2}{*}{ Parameter } & \multicolumn{3}{|c|}{ Metformin } & \multicolumn{3}{|c|}{ Disopyramide } & \multicolumn{3}{|c|}{$\begin{array}{c}\text { Disopyramide }+ \text { metformin } \\
\text { (SDA) }\end{array}$} & \multicolumn{3}{|c|}{$\begin{array}{c}\text { Disopyramide + metformin } \\
\text { (MDA) }\end{array}$} \\
\hline & $3^{\text {rd } h}$ & $6^{\text {th }} h$ & $12^{\text {th }} h$ & $3^{\text {rd } h}$ & $6^{\text {th }} h$ & $12^{\text {th }} \mathrm{h}$ & $3^{\text {rd } h}$ & $6^{\text {th }} h$ & $12^{\text {th }} \mathrm{h}$ & $3^{\text {rd } h}$ & $6^{\text {th }} h$ & $12^{\text {th }} \mathrm{h}$ \\
\hline Insulin $(\mu \mathrm{U} / \mathrm{mL})$ & $\begin{array}{c}10.84 \pm \\
03.45\end{array}$ & $\begin{array}{c}09.78 \pm \\
05.52\end{array}$ & $\begin{array}{l}8.23 \pm \\
06.33\end{array}$ & $\begin{array}{c}09.52 \pm \\
03.41\end{array}$ & $\begin{array}{c}09.02 \pm \\
02.56\end{array}$ & $\begin{array}{l}7.62 \pm \\
01.47\end{array}$ & $\begin{array}{l}15.87 \pm \\
03.71 *\end{array}$ & $\begin{array}{c}11.82 \pm \\
07.65\end{array}$ & $\begin{array}{c}08.83 \pm \\
04.43\end{array}$ & $\begin{array}{l}18.76 \pm \\
07.58 *\end{array}$ & $\begin{array}{c}12.54 \pm \\
02.34\end{array}$ & $\begin{array}{c}09.12 \pm \\
01.46\end{array}$ \\
\hline$\beta$-cell function & $\begin{array}{c}442.44 \pm \\
21.23\end{array}$ & $\begin{array}{c}238.5 \pm \\
32.65\end{array}$ & $\begin{array}{c}111.97 \pm \\
10.12\end{array}$ & $\begin{array}{c}216.36 \pm \\
12.7\end{array}$ & $\begin{array}{c}171.80 \pm \\
23.41\end{array}$ & $\begin{array}{c}95.25 \pm \\
11.34\end{array}$ & $\begin{array}{c}2441.5 \pm \\
85.23 *\end{array}$ & $\begin{array}{c}716.36 \pm \\
45.74\end{array}$ & $\begin{array}{c}136.89 \pm \\
27.12\end{array}$ & $\begin{array}{c}1563.3 \pm \\
76.45^{*}\end{array}$ & $\begin{array}{c}735.29 \pm \\
45.32\end{array}$ & $\begin{array}{c}162.85 \pm \\
13.54\end{array}$ \\
\hline
\end{tabular}

Notes: Data were expressed as mean $\pm \mathrm{SD}(\mathrm{N}=6)$; * significant at $\mathrm{P}<0.05$ compared to metformin control. Abbreviations: SDA - single dose administration; MDAmulti dose administration.

TABLE VI - Pharmacokinetic parameters after administration of metformin $70 \mathrm{mg} / 1.5 \mathrm{~kg}$ body weight, disopyramide $14 \mathrm{mg} / 1.5 \mathrm{~kg}$ body weight, single dose and metformin, disopyramide multiple dose and metformin in normal rabbits $(\mathrm{n}=6)$

\begin{tabular}{lccc}
\hline Kinetic parameters & Metformin & Single dose combination & Multiple dose combination \\
\hline $\mathrm{AUC}_{0-24}(\mathrm{ng} / \mathrm{mL} / \mathrm{h})$ & $14318.75 \pm 585.28$ & $14899.67 \pm 492.61$ & $15021.17 \pm 415.15$ \\
$\mathrm{AUMC}_{0-24}(\mathrm{ng} / \mathrm{mL} / \mathrm{h} * \mathrm{~h})$ & $258983.50 \pm 17280.0$ & $272597.60 \pm 12649.75$ & $277448.20 \pm 8921.80$ \\
$\mathrm{Kel}^{-1} \mathrm{~h}^{-1}$ & $0.035 \pm 00.00$ & $00.34 \pm 00.00$ & $00.03 \pm 00.00$ \\
$\mathrm{AUC}_{0-\infty}(\mathrm{ng} / \mathrm{mL} / \mathrm{h})$ & $26046.33 \pm 2313.86$ & $27521.08 \pm 1520.48$ & $28207.91 \pm 1000.40$ \\
$\mathrm{AUMC}_{0-\infty}\left(\mathrm{ng} / \mathrm{mL} / \mathrm{h}^{*} \mathrm{~h}\right)$ & $874116.1 \pm 129647.1$ & $941716.10 \pm 80069.00$ & $983130.40 \pm 44358.00$ \\
$\mathrm{~T}_{1 / 2}(\mathrm{~h})$ & $19.55 \pm 01.28$ & $20.05 \pm 00.75$ & $20.44 \pm 00.22$ \\
$\mathrm{Ka}\left(\mathrm{h}^{-1}\right)$ & $01.15 \pm 00.00$ & $01.15 \pm 00.00$ & $01.15 \pm 00.00$ \\
$\mathrm{Clearance}(\mathrm{mL} / \mathrm{h})$ & $2856.42 \pm 336.00$ & $2685.33 \pm 123.85$ & $2621.84 \pm 196.72$ \\
$\mathrm{Clearance}(\mathrm{mL} / \mathrm{h} / \mathrm{kg})$ & $1803.41 \pm 160.06$ & $1680.78 \pm 86.27$ & $1656.02 \pm 58.50^{*}$ \\
$\mathrm{Vdss}(\mathrm{mL})$ & $92488.59 \pm 6560.02$ & $89407.21 \pm 4621.44$ & $89063.05 \pm 6502.68$ \\
$\mathrm{Vdss}(\mathrm{mL} / \mathrm{kg})$ & $58425.81 \pm 1651.52$ & $55905.95 \pm 1471.56^{*}$ & $56248.81 \pm 1477.73 *$ \\
$\mathrm{Vdarea}(\mathrm{mL})$ & $80174.55 \pm 5404.59$ & $77699.32 \pm 4297.50^{*}$ & $77340.98 \pm 5667.54$ \\
$\mathrm{Vdarea}(\mathrm{mLkg})$ & $50652.97 \pm 1255.45$ & $48576.90 \pm 1253.19^{*}$ & $48844.94 \pm 1295.67$ \\
$\mathrm{MRT}(\mathrm{h})$ & $33.40 \pm 02.00$ & $34.16 \pm 01.06$ & $34.82 \pm 00.38$ \\
$\mathrm{C}_{\max }(\mathrm{ng} / \mathrm{mL})$ & $1184.00 \pm 35.70$ & $1209.00 \pm 17.62$ & $1219.66 \pm 17.22$ \\
$\mathrm{~T}_{\max }(\mathrm{h})$ & $03.00 \pm 00.00$ & $03.00 \pm 00.00$ & $03.00 \pm 00.00$ \\
\hline
\end{tabular}

*** Significant at $\mathrm{P}<0.001 ; * *$ Significant at $\mathrm{P}<0.01 ; *$ Significant at $\mathrm{P}<0.05$ compared to control metformin.

type-2 diabetes, as well as in type-1 diabetes along with insulin, and it is well established that its hypoglycemic effect is achieved by increasing glucose transport across the cell membrane, particularly in skeletal muscle. It has multiple antidiabetic effects, such as the inhibition of gluconeogenesis, delay of gastrointestinal absorption of glucose, reduction of food intake and prevention of body weight gain in obese patients with type-2 diabetes and in animal models of obesity (Bailey, Turner, 1996). Metformin increases plasma active glucagon, such as peptide-1(GLP-1), in obese non-diabetic subjects (Mannucci et al., 2001). The above mechanisms might also be responsible for its hypoglycemic effect in rats and rabbits.

The combination of disopyramide and metformin enhanced the hypoglycemic activity; this may be due to their added pharmacodynamic activity. Metformin is not metabolised by the hepatic microsomal enzyme system and is excreted unchanged. Hence, the enhancement of metformin action may not be due to the metabolic 
competitive inhibition exerted by disopyramide. Furthermore, since there was no change in the time of peak or duration of activity, the absorption does not appear to be affected. The metformin hypoglycemic response $(\%)$ exhibited only one peak, indicating that it does not enter the biliary excretion and enterohepatic circulation systems. Therefore, the increase in hypoglycemic response in the presence of disopyramide might be due to the combined pharmacodynamic effect. The single and multiple dose effects of the antiarrhythmic drug on metformin in normal and diabetic rats were similar, indicating that it did not affect the metabolism of metformin, even when administered longer term. The effect of disopyramide on metformin was found to be less severe and the combinations need not be considered as negative interactions.

The combination of metformin with disopyramide produced a blood glucose reduction earlier in rabbits than rats. However there was more blood glucose reduction in rats compared to rabbits, indicating that the rats were more sensitive to hypoglycemic agents than rabbits. The hypoglycemic effect of the combination of metformin with disopyramide is shown in Tables I, II and III.

The disopyramide and metformin combination produced a significant $(\mathrm{P}<0.05)$ elevation in insulin levels when compared to the metformin control group; the elevation was higher in the MDA treated group, as shown in Table IV.

In this study we investigated the effect of disopyramide on the activity of metformin with respect to glucose, insulin resistance and $\beta$ cell function using HOMA, which is a suitable and validated substitute measure (Bonora et al., 2000). In this study, the multiple dose effect of disopyramide on metformin activity was examined to determine the influence of long term treatment with disopyramide, because both are used in chronic conditions.

The pharmacodynamics of metformin were increased by disopyramide following single and multiple dose administration in rats and rabbits, even though disopyramide has shown notable alterations in glucoseinsulin homeostasis.

There was a marginal increase in pharmacokinetic parameters of metformin with multiple dose treatments of disopyramide, such as AUC, AUMC, clearance, Vdss, Vdarea and Cmax; and there were no significance differences in kinetic parameters between the single dose and multiple dose studies. The marginal increase in bioavailability cannot be due to improved absorption, since the absorption rate and absorption half-life of metformin was not altered, as shown in Table V. Metformin protein binding is almost negligible (Lee, 1996), whereas disopyramide is bound to the extent of $50 \%$ to $65 \%$ (Norpace(R), 1995). Metformin is not metabolised in the liver (Lee et al., 1996) so there is no possibility for interaction at the metabolism and distribution stages. Metformin is excreted unchanged through the kidney by the tubular secretion process; and disopyramide (40$50 \%$ ) is also excreted by a similar mechanism (Karim 1975; Ranney et al., 1971) in an unchanged form. Therefore, there may be slight possibility of interaction at the excretion stage, and the additive pharmacological action in improving the secretion of insulin/action contributes to the increased pharmacodynamic response of metformin. Hence, the interaction appears to be due to a pharmacodynamic mechanism and weak pharmacokinetic mechanism at the excretion stage.

\section{CONCLUSION}

This study validates the drug interaction in two dissimilar species, which indicates more probability of its occurrence in humans.

\section{ACKNOWLEDGEMENTS}

The authors thank Dr. Reddy's Laboratories, Hyderabad, and RPG Life Sciences Ltd.,

Mumbai, for providing the gift samples of metformin and disopyramide, respectively.

\section{REFERENCES}

Bailey CJ, Turner RC. Metformin. New Engl J Med. 1996;334(9):574-579.

Bonora E, Targher G, Alberiche M, Bonadonna RC, Saggiani F, Zenere MB, Monauni T, Muggeo M. Homeostasis model assessment closely mirrors the glucose clamp technique in the assessment of insulin sensitivity: studies in subjects with various degrees of glucose tolerance and insulin sensitivity. Diabetes Care. 2000;23(1):57-63.

Castano L, Eisenbarth GS. Type-I Diabetes: a chronic autoimmune disease of human, mouse, and rat. Annu Rev Immunol. 1990;8:647-679.

Ghosh MN. Fundamentals of experimental of experimental pharmacology scientific book agency. $2^{\text {nd }}$ edition. Kolkata: Scientific Book Agency;1984. 230 p. 
Glucophage(R) XR, metformin hydrochloride: product Information. Princeton, NJ: Bristol-Myers Squibb; 2001.

Glumetza(TM) extended-release oral tablets, metformin $\mathrm{HCl}$ extended-release oral tablets: product Information. Menlo Park, CA: Depomed Inc; 2006.

Karim A. The pharmacokinetics of Norpace(R). Angiology. 1975;26(1 Pt 2):85-98.

Lee AJ. Metformin in noninsulin-dependent diabetes mellitus. Pharmacotherapy. 1996;16(3):327-351.

Lloyd C, Smith J, Weinger K. Stress and diabetes: a review of the links. Diabetes Spectrum. 2005;18(2):121-127.

Mannucci E, Ognibene A, Cremasco F, Bardini G, Mencucci A, Pierazuoli E, Ciani S, Messeri G, Rotella CM. Effect of metformin on glucagons-like peptide 1 (GLP-1) and leptin levels in obese nondiabetic subjects. Diabetes Care. 2001;24(3):489494.

Mohan V, Deepa R, Rani SS, Premalatha G, Chennai Urban Population Study (CUPS No.5). Prevalence of coronary artery disease and its relationship to lipids in a selected population in South India: The Chennai Urban Population Study (CUPS No. 5). J Am Coll Cardiol. 2001;38(3):682-7.

Norpace(R), disopyramide: product Information. Chicago, IL: Searle Pharmaceuticals; 1995.
Oxford Centre for Diabetes Endocrinology and Metabolism. Diabetes Trial Unit. HOMA calculator. [cited 2009 Jul]. Available from: http://www.dtu.ox.ac.uk/homacalculator/ download.php.

Pentikainen PJ, Koivula IH, Hiltunen HA. Effect of rifampicin treatment on the kinetics of mexilitine. Eur J Clin Pharmacol. 1982;23(3):261-6.

Ranney RE, Dean RR, Karim A, Radzialowski FM. Disopyramide phosphate: pharmacokinetic and pharmacologic relationship of a new anti-arrhythmic agent. Arch Int Pharmacodyn Ther. 1971;191(1):162-88.

Tenenbaum A, Motro M, Schwammenthal E, Fisman EZ. Macrovascular complications of metabolic syndrome: an early intervention is imperative. Int J Cardiol. 2004;97(2):167-172.

Vinik A, Flemmer M. Diabetes and macrovascular disease. J Diabetes Complicat. 2002;16(3):235-245.

World Health Organization. WHO. Global health risks: mortality and burden of disease attributable to selected major risk. Geneva, Switzerland: World Health Organization; 2009. 62 p.

Received for publication on $05^{\text {th }}$ November 2016 Accepted for publication on $10^{\text {th }}$ April 2017 